\title{
Spatial and temporal heterogeneity of runoff and soil loss dynamics under simulated rainfall
}

\author{
Judit SZABÓ1 , Gergely JAKAB² and BogLÁrKa SZABÓ3
}

\begin{abstract}
The factors affecting soil erosion processes are complex and various, comprises two phases: detachment and transport by water. Previous studies indicated that initial moisture content, slope and soil crusts are playing an important role in soil erosion. The primary objectives of this study were to examine the sediment concentration and aggregate size distribution of the washed sediment. Aims were also to create different season specifically modelled situations in order to check runoff rates on bare soils under heavy rainfall. The experiments were conducted with a laboratory-scale rainfall simulator using a 1/2 HH 40 WSQ fulljet nozzle on eutric calcaric Cambisol loamic. Altogether, 72 soil loss samples were collected (6 separate precipitations, 3 time periods, 4 particle size fractions). The experiments indicated that the runoff rate was not increased by the presence of soil crusts, and even less sediment occurs on crusted surfaces. This sediment contained smaller fractions compared to recently tilled surface. The sediment concentration increased with the slope angle, but the runoff rates probably depend rather on the micro-morphology and initial moisture content of the surface. The main erosion process is the raindrop erosion after inland inundation and drought in gentle slopes, while the intermediate period of the precipitation is the most erosive. In general, the ratio of the macro aggregates in soil losses decrease and the ratio of the smaller fractions increase with the time during a precipitation event. Changing climate conditions are shown to have an effect on agricultural production through the temporal and spatial distribution of the erosion rates.
\end{abstract}

Keywords: soil erosion, rainfall simulation, runoff, aggregate size

\section{Introduction}

The soil loss by erosion is a widespread problem in agricultural areas. Soil erosion processes are affected by complex and various factors, including two phases: detachment and transport by water. A laboratory-scale rainfall simulator is an ideal tool for examining both phases of soil erosion on arable soils since most of the influential factors can be simulated and examined by its help. The advantages of the laboratory scale rainfall simulators are the

\footnotetext{
${ }^{1}$ Department of Environmental and Landscape Geography, Eötvös Loránd University, Faculty of Science. H-1117 Budapest, Pázmány Péter sétány 1/C. E-mail: szabojuditalexandra@gmail.com

${ }^{2}$ Geographical Institute, Research Centre for Astronomy and Earth Sciences, HAS. Budapest, H-1112 Budapest, Budaörsi út 45. E-mail: jakabg@mtafki.hu

${ }^{3}$ Department of Nature Conservation and Landscape Ecology, Szent István University, Faculty of Agricultural and Environmental Sciences. H-2100, Gödöllő, Páter K. u. 1. E-mail: bogi87@gmail.com
} 
followings: the effect of the soil heterogeneity is negligible, easy to concentrate on one or two factors and this is a fast method (GRISMER, M.E. 2010). According to Meyer, L.D. (1965) "The use of rainfall simulators generally provides a more rapid, efficient, controlled and adaptable tool than natural rainfall."

The first rainfall simulator in Hungary was designed by Kazó, B. (1966) in order to study infiltration, while KerÉNYI, A. (1986) concentrated on the role of initial erosion. Experiments were conducted to determine the erodibility ("factor K" in USLE equitation) of different Hungarian soils using a field scale rainfall simulator (CENTERI, Cs. and Császár, A. 2003; Centeri, Cs. and Pataki, R. 2003; JАKab, G. and Szalai, Z. 2005; Kertész, Á. and Centeri, Cs. 2006; Centeri Cs. et al. 2011).

Aggregates are groups of soil particles that are bound to each other. Their pattern - soil structure - has an influence on the physical and chemical processes of soils. Aggregate stability is one of the most important properties, which indicate soil resistivity against external effects as raindrop impacted aggregate breakdown (KeRÉNYI, A. 1986; Le BissonNAIS, Y. et al. 1989). The aggregate breakdown process is also connected with crust formation (West L.T. et al. 1992) and thus effects erosion rates.

Erosion studies usually use the measurement of the sediment concentrations, runoff rates and aggregate stability in order to examine the effect of the slope, initial moisture content, rainfall intensity, effect of the crust or the surface roughness on erosion rates (JIN, K. et al. 2008; Defersha, M.B. and Melesse, A.M. 2012).

The literature on simulated soil erosion experiments suggests several approaches. Defersha, M.B. and Melesse, A.M. (2012) examined the effect of the initial moisture content and slope steepness on erosion, whereas Le Bissonnais, Y. et al. (1989) studied the aggregate breakdown mechanism and soil crusting on pre-wetted and air-dry soils. JomAA, S., et al. (2012) concentrated on initial moisture contents and on the effect of surfi- cial rock fragments during rain splash erosion. Gómez, J.A., and Nearing, M.A. (2005) analysed the natural surface roughness while the effects of the impervious surface runoff were studied by Pappas, E.A. et al. (2008). Both provided different points of view regarding surface roughness. MoнаммаD, A. and ADAm, M. (2010) concentrated on the effect of vegetation and land use. However, the major problem with this kind of applications is that various simulators and methodologies exist. All the essential variables that indicate sediment dynamics are to be taken into consideration, especially sediment concentrations, sediment yield and transportability of soil particles (Defersha, M.B. and Melesse, A.M. (2012).

Nearing, M.A. et al. (2005) modelled different situations to present how the soil responses to potential climate change. Among others NeARING, M.A. et al. (2005) pointed out on the climate change impact of runoff and erosion, as the increasing rainfall intensity and rainfall amount together "will have greater impact on runoff and erosion than changes in rainfall amount alone." Recently, the meteorological conditions in Hungary got more and more inordinate. The probability of drought occurrence is estimated to increase; the wettest months are April and May while the driest are July and August (BARTHOLY, J. et al. 2014). Extreme rainfalls occur more often therefore agricultural areas will be potentially endangered by water erosion in a much wider range. This risk alternates during one year according to the different seasons.

The primary objectives of this study were to examine the sediment concentration and aggregate size distribution of the soil loss and to create different season-specific modelled situations in order to check the runoff rates. Three approaches were in the focus of the experiments on bare soil under heavy rainfall:

(1) Sedimentary crust formed after a precipitation event (WEST, L.T. et al. 1992). The effect of this crust on sediment concentration was examined in case of two different slope steepnesses (5\% and $12 \%$ ) by applying 
two simulated rainfalls within following two days.

(2) Two extreme soil moisture contents. The role of inland inundation and the drought were studied related to the changing climate conditions.

(3) Periods of each precipitation were studied beside the seasonal aspect. Aims were to compare the runoff dynamics and aggregate size distribution of the soil loss on different surfaces.

\section{Rainfall simulation}

Three fundamental criteria are commonly considered in designing a rainfall simulator (HALl, M.J. 1970), namely,

(1) the control of application rates in both time and space,

(2) the reproduction of drop-size distributions observed in different intensities of natural rainfall at the corresponding application rates,

(3) the reproduction of the terminal velocities of drops in natural rainfall.

GRISMER, M.E. (2010) summarized the rainfall simulation methodology, the simulator types,

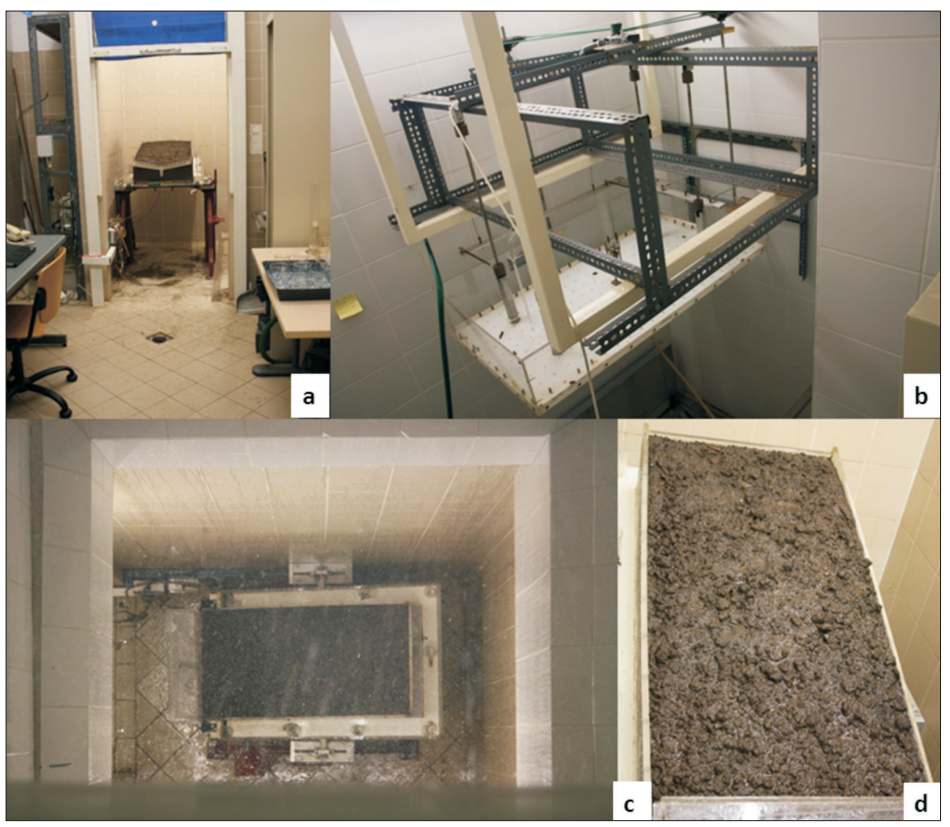

the erosion models and the rainfall characteristics. Several authors reported many types of laboratory scale rainfall simulators those can be used for research (e.g. Le Bissonnais, Y. et al. 1989; Gómez, J.A. and NEAring, M.A. 2005; Pappas, E.A. et al. 2008; Aksoy, H. et al. 2012; Defersha, M.B. and Melesse, A.M. 2012). According to Grismer, M. E (2010) the 80 percent of the simulators (both field and laboratory) are nozzle type simulators.

In this study, a laboratory rainfall simulation procedure was developed and utilized to examine aggregate size distribution of the soil loss and the runoff rates during the precipitation on different surfaces, but using the same soil. Our laboratory scale rainfall simulator is situated in Eötvös Loránd University, Faculty of Science, Budapest. The first stage of the simulator was designed by Zа́мвó and Weidinger (ZÁmbó, L. and Weidinger, T. 2006) (Photo 1).

For the first time, it had only an individual (pin) drop-former system $9 \mathrm{~m}$ above the monolith. In these days $1 / 2 \mathrm{HH} 40$ WSQ fulljet nozzle, 1/2 HH 50 WSQ fulljet nozzle can be used, too. The soil sample flume is $0.5 \mathrm{~m}$ $\times 1.0 \mathrm{~m} \times 0.2 \mathrm{~m}\left(0.1 \mathrm{~m}^{3}\right)$ and its steepness is adjustable (0-40\%). There are four taps on the bottom of the flume, so the leached water can be collected as well. The soft water from the plumbing runs through a pressure regulator system therefore no water tank is needed during the simulations.

Photo 1. The rainfall simulator: the rainfall simulator viewed from the front (a), drop-former system (b), the examined soil viewed from above with falling droplets (c), and the saturated soil (d) 


\section{Methodology}

\section{Rain simulation}

This paper presents data of six treatment combinations: recently tilled $(\mathrm{T})$ and crusty soil surface $(\mathrm{C})$ on two different slope steepness (5; 12), inland inundation (II) and drought (D) soil conditions on 2 percent slope steepness (Table 1). For each treatment the same $20 \mathrm{~cm}$ thick soil sample was packed into the flume overlaying a geotextile. 5T, 12T 2D treatments were applied on initially dry soil conditions, 5C, 12C treatments were applied on field capacity water content soil and 2II treatment was applied on the three weeks saturated soil.

The distributed soil was taken in Ceglédbercel, Hungary $\left(\mathrm{N} 47.249765^{\circ}\right.$, E19.678761ㅇ, $150 \mathrm{~m}$ a.s.l.). The mean annual temperature in the studied area is $10.8{ }^{\circ} \mathrm{C}$ and the annual precipitation is around $600 \mathrm{~mm}$ (DövéNYI, Z. 2010). The eroded eutric calcaric Cambisol loamic has 18.8 percent of $\mathrm{CaCO}_{3^{\prime}}$ the total organic carbon (TOC) content is 1 percent, and the $\mathrm{pH}$ is 7.5.

Drop forming nozzle system was chosen to examine the effect of intensive rainfall under different seasonal situations. Later, the same nozzle system can be used during field experiments in order to compare the results. The experiments were conducted in the laboratory using a 1/2 HH 40 WSQ fulljet nozzle which is widely used in rainfall simulation studies (Strauss, P. et al. 2000; Armstrong, Q. and Quinton, J.N. 2009). Since the cone basis of this nozzle was four times larger than the size of the monolith only one nozzle was applied.

The simulated rainfall characteristics depend on the nozzle type used and the pressure applied. According to the measurements of Strauss, P. et al. (2000) the kinetic energy of the rainfall simulated by the nozzle $1 / 2 \mathrm{HH}$ $40 \mathrm{WSQ}$ is $17 \mathrm{~kJ} \mathrm{~m}^{-2} \mathrm{~mm}^{-1}$ at $20 \mathrm{kPa}$. This value would correspond to approximately 65 percent of the kinetic energy of natural rainfall with the intensity of $50 \mathrm{~mm} \mathrm{~h}^{-1}$. Figure 1 shows

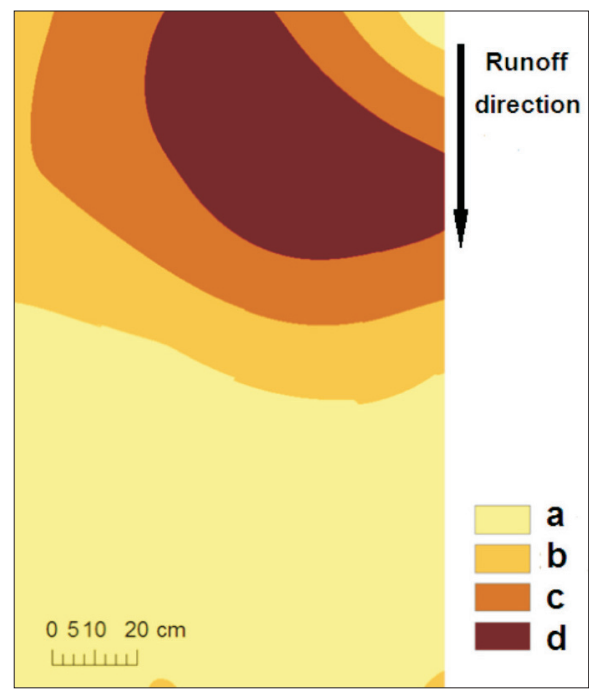

Fig. 1. Spatial distribution of simulated rainfall in $\mathrm{mm}$ after 20 minutes precipitation. The average intensity is $80 \mathrm{~mm} / \mathrm{h} . \mathrm{a}=26-28 \mathrm{~mm} ; \mathrm{b}=28-30 \mathrm{~mm}$; $=30-32 \mathrm{~mm}$; $\mathrm{d}=32-34 \mathrm{~mm}$

Table 1. Details of the six treatments

\begin{tabular}{|c|c|c|c|c|c|c|c|}
\hline $\begin{array}{c}\text { Simu- } \\
\text { lation } \\
\text { code }\end{array}$ & $\begin{array}{c}\text { Slope } \\
\text { steep- } \\
\text { ness } \\
\%\end{array}$ & Surface & $\begin{array}{c}\text { Time } \\
\text { min' sec" }\end{array}$ & 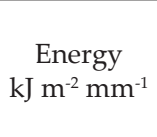 & $\begin{array}{c}\mathrm{CU} \\
\%\end{array}$ & $\begin{array}{l}\text { Median } \\
\text { drop } \\
\text { size mm }\end{array}$ & $\begin{array}{l}\text { Aim of the } \\
\text { treatment }\end{array}$ \\
\hline $5 \mathrm{~T}$ & 5 & Recently tilled & $42^{\prime} 11^{\prime \prime}$ & 17 & 98 & 1.95 & $\begin{array}{l}\text { Bare soils in autumn } \\
\text { and spring }\end{array}$ \\
\hline $5 \mathrm{C}$ & 5 & Crusty & $32^{\prime} 43^{\prime \prime}$ & 17 & 97 & 1.95 & Effect of the crust \\
\hline $12 \mathrm{~T}$ & 12 & Recently tilled & $33^{\prime} 34^{\prime \prime}$ & 17 & 94 & 1.95 & $\begin{array}{l}\text { Bare soils in autumn } \\
\text { and spring }\end{array}$ \\
\hline $12 \mathrm{C}$ & 12 & Crusty & $8^{\prime} 45^{\prime \prime}$ & 17 & 97 & 1.95 & Effect of the crust \\
\hline $2 \mathrm{II}$ & 2 & $\begin{array}{l}\text { After inland } \\
\text { inundation }\end{array}$ & $22^{\prime} 25^{\prime \prime}$ & 17 & 93 & 1.95 & $\begin{array}{l}\text { Extreme situation } \\
\text { (summer) }\end{array}$ \\
\hline $2 \mathrm{D}$ & 2 & $\begin{array}{l}\text { After drought } \\
\text { simulation }\end{array}$ & $29^{\prime} 22^{\prime \prime}$ & 17 & 96 & 1.95 & $\begin{array}{l}\text { Extreme situation } \\
\text { (summer) }\end{array}$ \\
\hline
\end{tabular}


the spatial distribution of simulated rainfall in $\mathrm{mm}$ after 20 minutes precipitation. The average intensity is $80 \mathrm{~mm} \mathrm{~h}^{-1}$. Simulated rainfall intensity was held constantly for these tests. The Christiansen's uniformity coefficient (CU) (Christiansen, J.E. 1942) which determine the uniformity of a sprinkler system was over 90 percent in case of all the six simulations, hence, the rainfall can be considered both spatially and temporary uniform.

Each runoff event was divided into three temporal phases, therefore the eroded sediment was collected in three periods (I, II, III) at three litres of the runoff intervals during the precipitation. Aims were to detect the temporal changes in aggregate sizes. Each three litre runoff phase soil loss was collected through sieve series with the following openings: $1 \mathrm{~mm}, 250 \mu \mathrm{m}$ and $50 \mu \mathrm{m}$ to a bucket. Therefore, by measuring the mass of fractions, the scale of the different aggregates is obtained directly. The capacity limitation of the sieves was equal to the sediment amount of three litres of water. During this study $a(2 \%), b(5 \%)$ and $c(12 \%)$ slope steepness were applied which represented:

a) flat plain where the inland inundation took place,

b) the average steepness of the agricultural areas in Hungary,

c) the suggested steepest slope in arable land areas.

Altogether 72 sample were collected (6 treatments $\times 3$ time periods $\times 4$ aggregate size fractions). The samples were used to calculate sediment concentration. Four sample repetitions of the untreated soil were also separated by this sieve system in prior to the measurements using the wet sieving method of KEMPER, D.W. and Rosenau, R.C. (1986) as a control.

The time was recorded after every 1 litre collected runoff. In the experiment $12 \mathrm{C}$ only three litres of runoff were collected (one period of the precipitation was represented by one litre runoff) because the high amount of the sediment on the sieves. In the experiment $12 \mathrm{~T}$ the time and litre data had to be corrected subsequently because of sieve sealing. Weights of dried soil losses were recorded at the nearest $0.01 \mathrm{~g}$.

\section{Results and discussion}

The changes of necessary time for 1 litre runoff are presented on Figure 2. There are two points in the zero line, the first point represents the time when runoff was started and the second means the time of surface ponding without any runoff. Runoff started after a twice longer period in case of $2 \mathrm{D}$ when the drought was simulated, because of the formation of big rifts according to the arid period, and because these needed to be infilled first. Shortest time was needed for the runoff in case of 2II, when the inland inundation was simulated. Runoff starts almost immediately, which means significantly 10 minutes differences (one fourth of the total time) (Table 1).

To compare the $5 \mathrm{~T}-5 \mathrm{C}$ and $12 \mathrm{~T}-12 \mathrm{C}$ cases, the runoff started earlier from the crusty surfaces. This was due to the bigger initial moisture content on the crusty surfaces compared to the tilled surfaces.

Three different runoff periods are separated on Figure 2. As first stage the curves are positioned in the zero line, without any runoff yet. The curves are different, because of the changing runoff rates and thus infiltration rates till the runoff of the third litre suspension. The ratio of the runoff and infiltration is constant during the third period (after the runoff of the third litre). The curves turn straight, which means that runoff and infiltration are in balance. The equations on Figure 2 show the third runoff periods of the 5T, 5C and 2II, 2D treatments. The curves of the $5 \mathrm{~T}$ and $5 \mathrm{C}$ have the same steepness, which means that crust evaluated this way is not characterized by any influences on runoff rates except the length of the time period before the runoff changed The curves of 12T, 12 C, 2II and 2D treatments are steeper than $5 \mathrm{~T}$ and $5 \mathrm{C}$ curves, therefore a higher infiltration rate is presumed in the latter cases. High runoff rate from 2 percent slope are assumed to be related to the degraded soil structure, but more experiments are needed in order to prove this phenomenon. The results of $12 \mathrm{~T}$ were corrected and at $12 \mathrm{C}$ the duration of the precipitation was too short. 


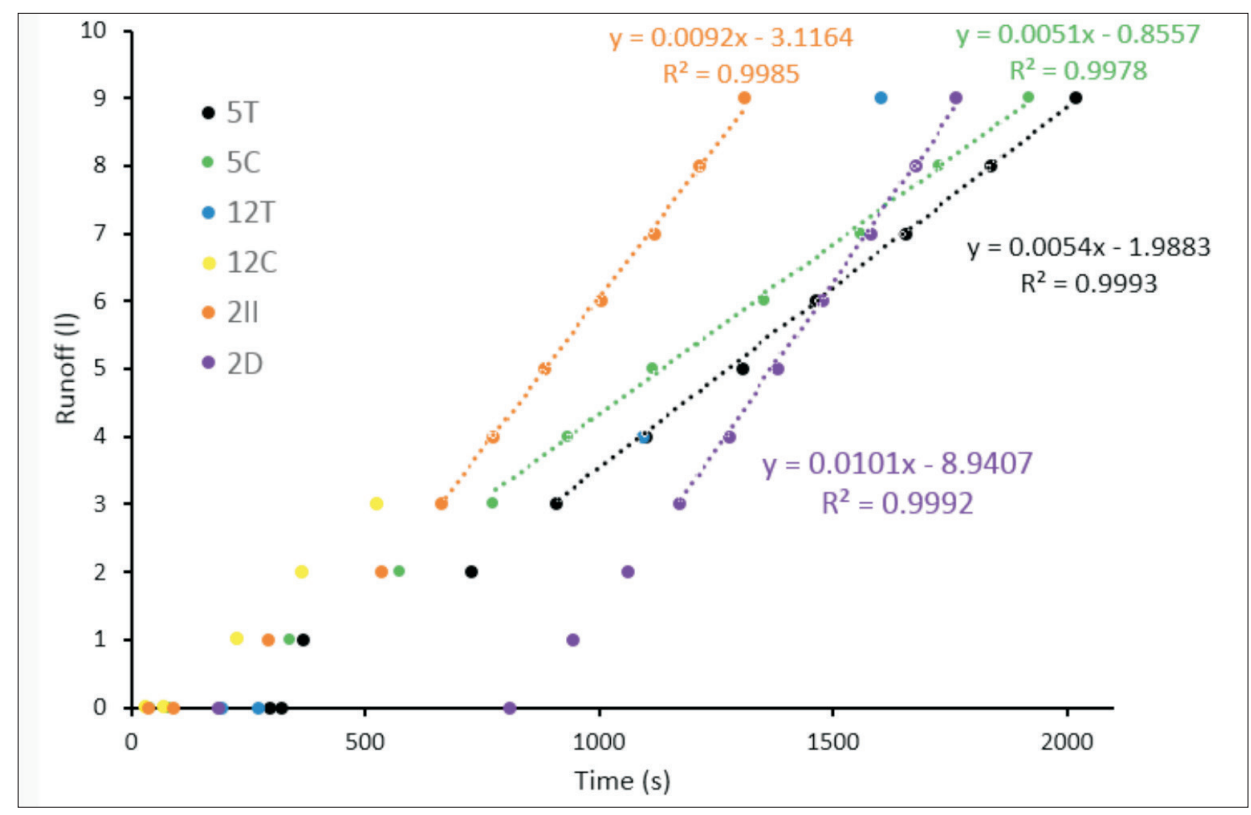

Fig. 2. The changes of necessary time for 1 litre runoff. There are two points in the zero line. The first point represents the time of surface ponding. There is no any runoff yet. Second point means the time when runoff has started. The equations refer to the 5T, 5C and 2II, 2D treatments after the third litre of runoff.

By this means the observed results were not examined in more detail.

Figure 3 represents the average sediment concentration increase with the slope angle. Runoff on steeper slopes contains greater amount of soil particles compared to gentle slopes. Runoff rates are not influenced by slope angles and thus do not influence the velocity of runoff. Defersha, M.B. and Melesse, A.M. (2012) got the same results in three different soil types with two different moisture contents and under three different rainfall intensities. On the other hand, Fox, D.M. et al. (1997) reported contradicting results on the slope dependence of the infiltration and crust formation on runoff rates. They assume that this contradiction may be connected to the different micro-morphology of the surfaces.

Table 2 summarizes the sediment concentration changes during the precipitation. The concentration of the sediment is higher at the tilled surface except the third period of the treatment $12 \mathrm{C}$ where the steep slope increased the concentration of the sediment, but more data is needed to determine the highest concentration which has effect on the mean values in Figure 3. During the precipitation in case of $12 \mathrm{~T}$ fourfold measure of the sediment was washed down compared to the case of the $5 \mathrm{~T}$ in the first period. In the second period, the differences decreased threefold and to the end of the precipitation increased a little bit more than fourfold again. During the three periods of the precipitation, the rates in case of $5 \mathrm{C}$ and $12 \mathrm{C}$ treatments are bigger, 5.0, 3.5 and 5.0-fold respectively.

Almost the same density sediment was washed down from the surfaces of 2II and $2 \mathrm{D}$ precipitation and there was no significant difference between the periods of the precipitation. It was one order less dense than the others (Table 2, Figure 3), therefore, we can state that extreme initial moisture content has no effect on sediment concentration changes. Wetting and drying cycles have influence on the soil structure (BoDNER, G. et 


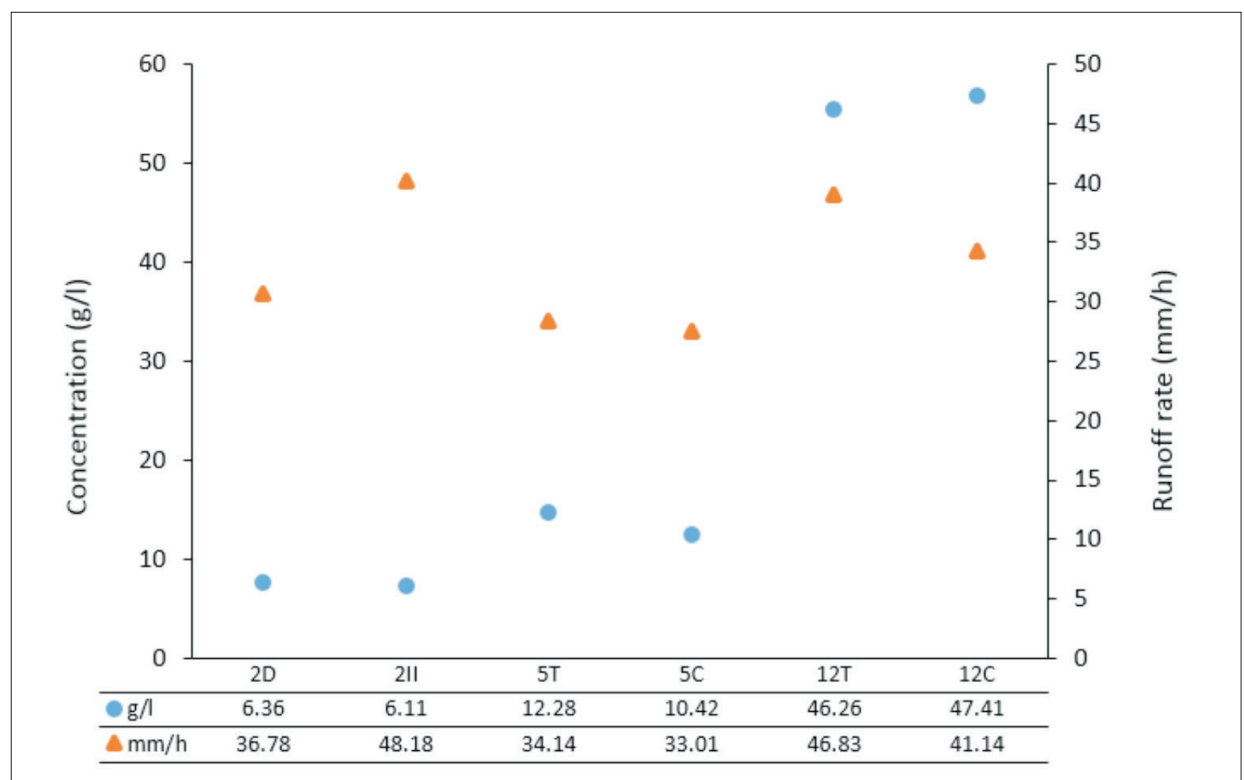

Fig. 3. The sediment concentrations and runoff rates of the six treatments

al. 2013) therefore erosion affects differently in extreme moisture content soils. The treatment of 2D and 2II had the lowest soil content in the runoff because the structure of the soil and aggregate stability was very weak. Aggregates were easy to detach to elementary particles, and due to the gentle slope, the runoff was able to transport only finer particles. Initial erosion and raindrop impact are supposed to have more significant influence on particle redistribution in these two cases. The lowest sediment concentration and highest runoff rate were observed for 2B.

Areas covered by inundation are generally flat or have only gentle slopes hence the main risk there is not the runoff, rather the structure degradation. The fraction content and sediment concentration are almost the same due to the degraded structure. The sediment concentration trend is the same in all cases during the precipitation. The second period is the most erodible, except the $12 \mathrm{C}$ when the sediment concentration increased (Table 2).

Table 3 summarizes the results of all (72) soil loss samples and the 4 sample sets of the original soil. Washed sediment lacked macro aggregates larger than $1 \mathrm{~mm}$. On the average, the difference is 38 percent between the ratio of the aggregates $>1 \mathrm{~mm}$ in original soil sample and the soil loss. This fraction is underrepresented

Table 2. Sediment concentration changes during the precipitation in the six treatments

\begin{tabular}{l|c|c|c|c|c|c|c}
\hline \multirow{2}{*}{\multicolumn{1}{c|}{ Periods }} & $5 \mathrm{~T}$ & $5 \mathrm{C}$ & $12 \mathrm{~T}$ & 12C & \multicolumn{2}{c|}{ 2II } & 2D \\
\cline { 2 - 7 } & \multicolumn{7}{|c|}{$\mathrm{g} \mathrm{l}^{-1}$} \\
\hline Period I & 10.95 & 7.46 & 43.88 & 35.19 & 5.89 & 6.65 \\
Period II & 15.19 & 12.09 & 49.93 & 43.00 & 6.16 & 6.16 \\
Period III & 10.69 & 11.70 & 45.79 & 64.03 & 6.29 & 6.26 \\
Whole precipitation & 12.28 & 10.42 & 46.26 & 47.41 & 6.11 & 6.35 \\
\hline
\end{tabular}


Table 3. The aggregate size distribution results of all the 72 sediment samples, and the 4 sample of the original soil

\begin{tabular}{|c|c|c|c|c|c|c|c|}
\hline \multirow{2}{*}{$\begin{array}{l}\text { Size, } \\
\mu \mathrm{m}\end{array}$} & $\begin{array}{c}\text { Untreated } \\
\text { soil }\end{array}$ & $5 \mathrm{~T}$ & $5 C$ & $12 \mathrm{~T}$ & $12 \mathrm{C}$ & $2 \mathrm{II}$ & $2 \mathrm{D}$ \\
\hline & \multicolumn{7}{|c|}{$\%$} \\
\hline \multicolumn{8}{|c|}{ Period I } \\
\hline$>50$ & 4.81 & 32.56 & 29.59 & 14.08 & 36.54 & 52.70 & 70.16 \\
\hline $50-250$ & 24.63 & 19.84 & 47.88 & 52.50 & 29.87 & 43.07 & 19.91 \\
\hline $250-1,000$ & 32.00 & 46.96 & 22.49 & 32.77 & 31.74 & 3.93 & 9.63 \\
\hline $1,000<$ & 38.57 & 0.64 & 0.04 & 0.66 & 1.85 & 0.29 & 0.30 \\
\hline \multicolumn{8}{|c|}{ Period II } \\
\hline$>50$ & 4.81 & 29.43 & 51.12 & 12.46 & 33.86 & 79.88 & 72.87 \\
\hline $50-250$ & 24.63 & 44.58 & 35.13 & 49.22 & 36.72 & 14.01 & 17.65 \\
\hline $250-1,000$ & 32.00 & 25.81 & 13.53 & 37.52 & 28.26 & 5.73 & 9.31 \\
\hline $1,000<$ & 38.57 & 0.18 & 0.22 & 0.79 & 1.16 & 0.38 & 0.16 \\
\hline \multicolumn{8}{|c|}{ Period III } \\
\hline$>50$ & 4.81 & 38.01 & 49.97 & 13.30 & 28.99 & 80.06 & 72.38 \\
\hline $50-250$ & 24.63 & 42.75 & 37.69 & 49.91 & 40.93 & 13.47 & 18.79 \\
\hline $250-1,000$ & 32.00 & 18.64 & 12.19 & 35.96 & 28.44 & 6.10 & 8.62 \\
\hline $1,000<$ & 38.57 & 0.61 & 0.14 & 0.84 & 1.64 & 0.37 & 0.21 \\
\hline
\end{tabular}

in the sediment with less than 1 percent except for $12 \mathrm{C}$. During the rain, there were no trends present, but the mass of the soil loss in this fraction was under $1 \mathrm{~g}$ (therefore the dynamics were not relevant). The lack of this fraction was probably connected to the raindrop impact and partly to macro aggregates broke down to micro aggregates (50-250 $\mu \mathrm{m}$ ) and elementary particles $(<50 \mu \mathrm{m})$ due to slaking (as it was also reported by Le Bissonnais, Y. 1996).

Generally, the rate of the soil loss of recently tilled surfaces (5T and 12T) was larger in the $250-1,000 \mu \mathrm{m}$ fraction than in the soil loss of crusty surfaces (5C and $12 \mathrm{C}$ ). The proportion of this fraction was also larger at 12 percent slope steepness with the exception of the I. period of 5T when this ratio is the largest. The proportion of $250-1,000 \mu \mathrm{m}$ was under 10 percent in case of $2 \mathrm{II}$ and $2 \mathrm{D}$.

The fraction of 50-250 $\mu \mathrm{m}$ showed the largest proportions in the soil loss compared to the original soil sample. The same trend was presented in the $250-1,000 \mu \mathrm{m}$ fraction, where the tilled surface and the slope increased the proportion of this fraction (with the exception of the I. period of 5T, where the dominant fraction is the $250-1,000 \mu \mathrm{m}$ ). Treatment 2II and 2D showed decreasing trend during the precipitation.
Soil loss was larger than in the case of the original soil, concerning the fraction of $<50 \mu \mathrm{m}$ at all proportions. The largest ratio was found in treatment 2II, whilst the last period of the precipitation. This fraction was characteristic of treatment 2II and 2D has with over 50 percent rate.

To conclude, the runoff was faster from crusty or wetter surfaces (5C, 12C, 2II), however, larger aggregates were eroded from recently tilled surfaces (5T, 12T). The runoff of 2D started late but it was fast. The aggregate size distribution changed in the eroded sediment, which depended on the time frame of the treatment.

\section{Conclusion}

Laboratory scale rainfall simulator was used to examine soil erosion and runoff under six different conditions represented by different seasonal situations. Our results showed that the same soil sample under the same precipitation was eroded totally different. Crusting had no definite role in infiltration mitigation; moreover, we measured ambiguous data regarding soil loss reduction.

In general, the ratio of the macro aggregates decreased and the ratio of the micro aggre- 
gates and clay fraction increased in the sediment during the precipitation. Larger amount of sediment was transported from steeper slopes by runoff, but larger aggregates were washed down from the tilled surface. The most erodible fractions play an important role in nutrient supply of agricultural areas thus the erosion protection is relevant. Changing climate conditions have even more effect on agricultural production through the temporal and spatial distribution of the erosion rates. It is necessary to understand the erosion processes under different conditions.

The next stage of our research is to perform more experiments at the laboratory by using other soil samples and to compare and verify the results live on the field. Further studies are planned concerning the elementary particles of the aggregate fraction, the organic matter content and the clay mineral composition of the sediment. Future aims are to find the main reason of surficial variability, i.e. to detect the differences among the seasonal erosion characteristics under heavy rainfall situations.

\section{REFERENCES}

Aksoy, H., Erdem Unal, N., Cokgor, S., Gediklia, A., Yoonb, J., KocaA, K., Incia, S.B. and Erisc, E. 2012. A rainfall simulator for laboratory-scale assessment of rainfall-runoff-sediment transport processes over a two-dimensional flume. Catena 98. 63-72.

Armstrong, Q. and Quinton, J.N. 2009. Pumped rainfall simulators: the impact of rain pulses on sediment concentration and size. Earth Surface Processes and Landforms 34. (9): 1310-1314.

Bartholy, J., Pongrácz, R. and Pieczka, I. 2014. How the climate will change in this century? Hungarian Geographical Bulletin 63. (1): 55-67.

Bodner, G., Scholl P. and Kaul, H.P. 2013. Field quantification of wetting-drying cycles to predict temporal changes of soil pore size distribution. Soil and Tillage Research 133. 1-9.

Centeri, Cs. and Császár, A. 2003. A talajképződés és az erózió által kiváltott talajpusztulás kapcsolata a Tihanyi-félsziget példáján (The connection of soil formation and erosion induced soil loss in the Tihany Peninsula). Tájökológiai Lapok 1. (1): 81-85.

Centeri, Cs. and Pataki, R. 2003. Hazai talajerodálhatósági értékek meghatározásának fontossága a talajveszteség tolerancia értékek tükrében (Importance of determining Hungarian soil erodibility values in connection with the soil loss tolerance values). Tájökológiai Lapok 1. (2): 181-192.

Centeri, Cs., Jakab, G., Szalai, Z., Madarász, B., SisÁk, I., CsepinszKY, B. and BíRó, Zs. 2011. Rainfall simulation studies in Hungary. In Soil Erosion: Causes, Processes and Effects. Ed.: Fournier, A.J. New York, NOVA Science Publisher, 177-217.

Christiansen, J.E. 1942. Irrigation by Sprinkler. Agriculture Experimental Station Bulletin 37. 1-124.

Defersha, M.B. and Melesse, A.M. 2012. Effect of rainfall intensity, slope and antecedent moisture content on sediment concentration and sediment enrichment ratio. Catena 90. 47-52.

DövÉNyI, Z. (ed.) 2010. Magyarország kistájainak katasztere (Cadastre of natural micro-regions of Hungary). 2. átdolgozott és bővített kiadás. Budapest, MTA Földrajztudományi Kutatóintézet, 876 p.

Fox, D.M., Bryan, R.B. and Price, A.G. 1997. The influence of slope angle on final infiltration rate for interrill conditions. Geoderma 80. (1-2): 181-194.

Gómez, J.A. and NEARING, M.A. 2005. Runoff and sediment losses from rough and smooth soil surfaces in a laboratory experiment. Catena 59. 253-266.

Grismer, M.E. 2010. Rainfall Simulation Studies - A Review of Designs, Performance and Erosion Measurement Variability. TSC Rainsim workshop. 110 p.

Hall, M. J. 1970. A critique of methods of simulating rainfall. Water Resources Research 6. (4): 1104-1113.

JАКАВ, G. and SzALAI, Z. 2005. Barnaföld erózióérzékenységének vizsgálata esőztetéssel a Tetves-patak vízgyújtőjén (Brown soill erodibility measurements in the Tetves Stream catchment using rainfall simulator). Tájökológiai Lapok 3. (1): 177-189.

Jin, K., Cornelis, W.M., Gabriels, D., Schiettecatte, W., De Neve, S., Lu, J., Buysse, T., Wu, H., Cai, D., Jin, J. and HarmanN, R. 2008. Soil management effects on runoff and soil loss from field rainfall simulation. Catena 75. (2): 191-199.

JomaA, S., Barry, D.A., Brovelli, A., Heng, B.C.P., Sander, G.C., Parlange, J.-Y. and Rose, C.W. 2012. Rain splash soil erosion estimation in the presence of rock fragments. Catena 92. 38-48.

KAzó, B. 1966. A talajok vízgazdálkodási tulajdonságainak meghatározása mesterséges esőztető készülékkel (Assessment of water management properties of soils with rainfall simulator device). Agrokémia és Talajtan 15. (2): 239-252.

Kemper, D.W. and Rosenau, R.C. (1986) Aggregate stability and aggregate size distribution. In: KLUte, A. (Ed.), Methods of Soil Analysis Part 1. ASA-SSSA, Madison, WI, 425-442.

KerényI, A. 1986. Az iniciális erózió laboratóriumi vizsgálata homokon és szerkezetes talajokon (Laboratory simulation study on the initial erosion of sand and soils with well developed structure). Agrokémia és Talajtan 35. 18-38.

Kertész, Á. and Centeri, Cs. 2006. Hungary. In Soil erosion in Europe. Eds. Boardman, J. and Poesen, J. Chichester, John Wiley \& Sons Ltd. 139-154. 
Le Bissonnais, Y. 1996. Aggregate stability and assessment of soil crustability and erodibility: I. Theory and methodology. European Journal of Soil Science 47. 425-437.

Le Bissonnais, Y., Bruand, A. and Jamagne, M. 1989. Laboratory experimental study of soil crusting: relation between aggregate breakdown mechanism and crust structure. Catena 16. 377-392.

MEYer, L.D. 1965. Simulator of rainfall for soil erosion research. Transactions of the ASAE 8. (1): 63-65.

Moнammad, A.G. and Adam, M.A. 2010. The impact of vegetative cover type on runoff and soil erosion under different land uses. Catena 81. 97-103.

Nearing, M.A., Jetten, V., Baffaut, C., Cerdan, O., Couturier, A., Hernandez, M., Le Bissonnais, Y., Nichols, M.H., Nunes, J.P., Renschler, C.S., Souchére, V. and VAN Oost, K. 2005. Modelling response of soil erosion and runoff to changes in precipitation and cover. Catena 61. (2): 131-154.

PAppas, E.A., Smith, D.R., Huang, C.W.D. and Shuster BontA, J.V. 2008. Impervious surface impacts to runoff and sediment discharge under laboratory rainfall simulation. Catena 72. (1): 146-152.
Strauss, P., Pitty, J., Pfeffer, M. and Mentler, A. 2000. Rainfall simulation for outdoor experiments. In Current Research Methods to Assess the Environmental Fate of Pesticides. Eds. JAmet, P. and CoRnejo, J. Idaho Falls, USA, INRA Editions, 329-333.

West, L.T., Chiang, S.C. and Norton, L.D. 1992. The morphology of surface crusts. In Soil Crusting: Chemical and Physical Processes. Advanced Soil Science. Eds Sumner, M.E. and Stewart, B.A. Boca Raton, Lewis Publisher, 73-92.

ZÁmbó L. Weidinger T. 2006. Karsztkorróziós talajhatás néhány tényezőjének vizsgálata esőszimulációs kísérletek alapján (Investigations of karst corrosional soil effects based on rainfall simulator experiment). In Táj, környezet és társadalom. Ünnepi tanulmányok Keveiné Bárány Ilona professzor asszony tiszteletére. Eds.: KIss, A., Mezősı, G. and SüMeghy, Z. Szeged, SZTE Éghajlattani és Tájföldrajzi Tanszék - Természeti Földrajzi és Geoinformatikai Tanszék, 757-765. 